\author{
Iwona Sagan \\ Magdalena Szmytkowska \\ Grzegorz Masik \\ Katedra Geografii Ekonomicznej, Instytut Geografii \\ Uniwersytet Gdański
}

\title{
Postawy przedsiębiorcze mieszkańców Gdyni
}

Badania dotyczące przedsiębiorczości skupiają się zazwyczaj na jej aspekcie ekonomicznym. Dokonuje się oceny roli przedsiębiorstw na lokalnym rynku pracy i wskazuje ich znaczenie dla bazy ekonomicznej miasta, przy zastosowaniu takich typowych ekonomicznych miar, jak przychody ze sprzedaży towarów i usług. Przedmiotem niniejszego opracowania są przede wszystkim społeczne i psychologiczne aspekty przedsiębiorczości., a podstawowym celem jest określenie i ocena potencjału przedsiębiorczości mieszkańców Gdyni. Zagadnienia podjęte $\mathrm{w}$ pracy oraz postawione cele badawcze wymagały zastosowania metod analizy ilościowej i jakościowej. W tym celu w 2007 r. przeprowadzono reprezentatywne terenowe badania ankietowe $\mathrm{z}$ zastosowaniem metody random route na próbie 1000 osób oraz serię 100 bezpośrednich wywiadów pogłębionych, z doborem respondentów metodą kuli śnieżnej (zob. Babbie 2004).

\section{Przedsiębiorczość jako kategoria społeczna i osobnicza}

Przedsiębiorczość to „branie czegoś przed siebie”, czyli podejmowanie się realizacji nowych i trudnych zadań. W nieco węższym znaczeniu przedsiębiorczość jest opisywana jako zespół cech warunkujących osiąganie sukcesu w organizowaniu, kierowaniu i kontrolowaniu działalności firmy. Oznacza zatem gotowość i zdolność podejmowania i rozwiązywania w sposób twórczy nowych problemów, umiejętność wykorzystania pojawiających się szans oraz elastyczne przystosowywanie się do zmiennych warunków funkcjonowania. Społeczny aspekt przedsiębiorczości trafnie ujął Sztucki (1996, s. 12): „działalność gospodarcza nie jest wyłącznie pogonią za pieniądzem; jest również dążeniem do wyróżnienia się i wynikającego stąd poczucia własnej godności”.

Ekonomiści słusznie argumentują, że na rozwój przedsiębiorczości w głównej mierze wpływają ekonomiczne i prawne uwarunkowania działalności gospodarczej. To podejście powinno jednak zostać uzupełnione o analizę czynników psychologicznych w ożywianiu przedsiębiorczości. Praktycznie w każdych warunkach obserwujemy lukę pomiędzy różnego typu działaniami władz mającymi na celu pobudzenie przedsiębiorczości a faktycznym odzewem członków społeczności, do których te działania są adresowane. Ta rozbieżność pomiędzy proprzedsiębiorczą polityką a faktycznym zachowaniem aktorów na rynku może być $\mathrm{w}$ pełni zinterpretowana jedynie $\mathrm{z}$ wykorzystaniem wiedzy na temat psychologicznych uwarunkowań osobowości potencjalnego przedsiębiorcy. Do istotnych z tego punktu widzenia działań należy m.in. organizacja treningów dla już działających przedsiębiorców, stymulacja potencjalnych przedsiębiorców do działań na rzecz uruchomienia własnej działalności, właściwa selekcja kandydatów do wsparcia kredytowego, stymulacja właścicieli firm do 
zwiększania skali działania czy wspomaganie systemu kształcenia w taki sposób, aby rozwijał on wśród uczniów umiejętności i motywacje do podejmowania pracy na własny rachunek. Wielu przedsiębiorcom brak odpowiednich umiejętności i wiedzy, kluczowych dla odniesienia sukcesu; popełniają oni poważne błędy w relacjach z klientami, kontrahentami, bankami czy innymi podmiotami kluczowymi dla powodzenia działalności. Czynniki te mają charakter psychologiczny; trzeba mieć ich świadomość, aby móc na nie wpływać i zmieniać je. Działania na rzecz kształtowania odpowiednich psychologicznie postaw przedsiębiorczych są oddolne. Nie prowadzą bezpośrednio do zmiany warunków makroekonomicznych, ale skupiają się na konkretnych działaniach konkretnych ludzi, w oparciu o analizę możliwości i ograniczeń poprawy ich sytuacji. Są zatem ze swej natury działaniami, które jedynie w skali lokalnej mogą być skutecznie podejmowane, co nie znaczy, że w dłuższej perspektywie nie mogą pośrednio doprowadzić do generalnych zmian warunków ekonomicznych.

\section{Cechy osobowości człowieka przedsiębiorczego}

Przedsiębiorczymi zwykło się nazywać te osoby, które osiągają sukces na rynku. Można więc powiedzieć, że przedsiębiorczość jest w pewnej mierze wrodzoną dyspozycyjnością psychiczną oraz umiejętnością nabytą w wyniku nauki. Tak jak w innych dziedzinach życia ludzkiego, największe sukcesy odnosi jednostka uzdolniona naturalnie, która zdobyła określone umiejętności dzięki nauce oraz towarzyszącej nauce praktyce. Osoba posiadająca znamię przedsiębiorczości musi zdobyć niezbędną wiedzę o obszarze swojego przyszłego działania, a zarazem wiedzę o rynku. Nieodłączne cechy ludzi przedsiębiorczych to dynamika działania połączona $\mathrm{z}$ aktywnością życiową oraz przejawianie inicjatywy w działaniu. Ludzie bierni i pasywni mogą być dobrymi wykonawcami poleceń osób przedsiębiorczych, nieobawiających się podjęcia ryzyka w realizacji przedsięwzięcia. Kluczową cechą osoby przedsiębiorczej jest zrównoważenie intelektualne i emocjonalne, czyli umiejętność wyważenia własnych pomysłów, odniesienia ich do realiów, a w rezultacie - ich konsekwentna realizacja. Za istotne dla kształtowania postawy przedsiębiorczej uważa się ponadto:

- odwagę, decydującą o podejmowaniu ryzyka i wzmacniającą wolę osiągnięcia sukcesu;

- pewność siebie i wiarę w sens własnych działań;

- ambicję.

Oprócz pewnych cech psychicznych i charakterologicznych, osoba przedsiębiorcza powinna mieć zdolność przewodzenia i współpracy z innymi ludźmi. Umiejętna organizacja pracy i jasne określenie zakresu obowiązków przez pracodawcę zdecydowanie poprawiają funkcjonowanie firmy. Ponadto, działalność rynkowa wymaga od przedsiębiorcy cierpliwości i okazywania życzliwości w nawiązywaniu i utrzymywaniu kontaktów z innymi osobami działającymi na rynku.

\section{Postawy przedsiębiorcze}

Inicjatywa, zdolność przekonywania, raczej umiarkowana niż duża skłonność do podejmowania ryzyka, elastyczność, kreatywność, niezależność/autonomia, zdolność rozwiązywania problemów, potrzeba osiągnięć, wyobraźnia, przekonanie o kontroli własnego przeznaczenia, przywództwo, umiejętność ciężkiej pracy i inne cechy wymieniane przez Gibba (1993) kształtują postawy przedsiębiorcze w określonej społeczności. Jak zauważa Pomykało (1995), cechy te mogą występować u każdego, z tym, że stopień „wyposażenia” w nie jest różny. Jedni ludzie są bardziej kreatywni, mają większą skłonność do niezależności, potrafią i chcą o wiele ciężej i intensywniej pracować niż inni. Zależy to w dużym stopniu od charakteru podejmowanych działań, warunków, a także otoczenia. Sprzyjające warunki mogą sprawić, że ludzie stają się 
bardziej przedsiębiorczy albo wykazują cechy przedsiębiorcze wcześniej nieujawnione. W tab. 1 zostały uwzględnione ogólne kategorie psychologiczne, które charakteryzują przedsiębiorczość bądź jej brak.

Tabl. 1. Zestawienie cech psychicznych sprzyjających działaniom przedsiębiorczym i utrudniających je

\begin{tabular}{|c|c|c|}
\hline Cechy utrudniające & Kategorie ogólne & Cechy ułatwiające \\
\hline $\begin{array}{l}\text { - poniżanie się } \\
\text { - liczenie głównie na opiekę } \\
\text { i oparcie u innych } \\
\text { - uległość } \\
\text { - odrzucenie i izolacja } \\
\text { - usprawiedliwianie siebie za brak } \\
\text { sukcesów }\end{array}$ & $\begin{array}{l}\text { POTRZEBY } \\
\text { PSYCHICZNE }\end{array}$ & $\begin{array}{l}\text { - tendencje do dominowania } \\
\text { - skłonność do wyczynu i posiadania } \\
\text { - dążenie do własności i autonomii } \\
\text { - orientacja na osiągnięcie sukcesu } \\
\text { i władzy }\end{array}$ \\
\hline $\begin{array}{l}\text { - lęki } \\
\text { - niechęć, bojaźń zamiast } \\
\text { samodzielności } \\
\text { - chęć utrzymania tego, } \\
\text { co się posiada, a nie jego } \\
\text { pomnażanie }\end{array}$ & MOTYWACJA & $\begin{array}{l}\text { - umiejętności przezwyciężania lęków } \\
\text { i depresji oraz różnych zagrożeń } \\
\text { - tendencja do powiększania stanu } \\
\text { posiadania } \\
\text { - orientacja na osiągnięcie i sukces } \\
\text { - motywy „bycia przedsiębiorczym” }\end{array}$ \\
\hline $\begin{array}{l}\text { - trudności w podejmowaniu decyzji } \\
\text { - chwiejność } \\
\text { - „wyuczona bezradność” }\end{array}$ & DECYZJE & $\begin{array}{l}\text { - zdecydowanie } \\
\text { - decyzje adekwatne do sytuacji } \\
\text { - konsekwencja }\end{array}$ \\
\hline $\begin{array}{l}\text { unikanie sytuacji i decyzji } \\
\text { obciążonych ryzykiem }\end{array}$ & RYZYKO & $\begin{array}{l}\text { - traktowanie sytuacji ryzykownych } \\
\text { jako szans na sukces } \\
\text { - podejmowanie decyzji obciążonych } \\
\text { ryzykiem }\end{array}$ \\
\hline $\begin{array}{l}\text { - brak odporności psychicznej } \\
\text { - niski próg stresu i frustracji }\end{array}$ & $\begin{array}{c}\text { SUKCES } \\
\text { I NIEPOWODZENIE }\end{array}$ & $\begin{array}{l}\text { - odporność psychiczna } \\
\text { - wysoki próg stresu i frustracji } \\
\text { - umiejętność działania w sytuacjach } \\
\text { trudnych }\end{array}$ \\
\hline $\begin{array}{l}\text { - } \text { postawa zachowawcza } \\
\text { - konformizm } \\
\text { - } \text { algorytmiczny styl działania } \\
\text { - brak zdolności twórczych }\end{array}$ & $\begin{array}{l}\text { INNOWACYJNOŚĆ } \\
\text { I TWÓRCZOŚĆ }\end{array}$ & $\begin{array}{l}\text { - postawa pionierska } \\
\text { - zdolności twórcze } \\
\text { - pomysłowość } \\
\text { - wyobraźnia i myślenie dywergencyjne } \\
\text { - intuicja }\end{array}$ \\
\hline $\begin{array}{l}\text { - introwersja } \\
\text { - trudności w kontaktach } \\
\text { i współpracy } \\
\text { - brak zdolności przywódczych }\end{array}$ & WSPÓŁPRACA & $\begin{array}{l}\text { - ekstrawersja } \\
\text { - zdolności przywódcze } \\
\text { - twórcze kierowanie } \\
\text { - zaufanie u innych } \\
\text { - umiejętność negocjacji } \\
\text { i mobilizowania innych } \\
\text { - znajomość potrzeb ludzi }\end{array}$ \\
\hline $\begin{array}{l}\text { - lęki i obawy } \\
\text { - lenistwo } \\
\text { - pesymizm i in. }\end{array}$ & BARIERY & $\begin{array}{l}\text { - optymizm i aktywność } \\
\text { - znajomość siebie } \\
\text { - postawa abarietyczna }\end{array}$ \\
\hline - melancholik & TEMPERAMENT & $\begin{array}{l}\text { - sangwinik } \\
\text { - duża energia i zrównoważenie }\end{array}$ \\
\hline
\end{tabular}

Źródło: Pomykało 1995. 
Znaczenie aspektu psychologicznego w modelu uwarunkowań prowadzących do osiągnięcia sukcesu w działalności przedsiębiorczej zaprezentowano w formie schematu (ryc. 1). Kolejność oddziaływania wzajemnie ze sobą powiązanych elementów w procesie osiągania sukcesu przedsiębiorczego oznaczono literami. Cechy osobowości są pierwszym i krytycznym elementem modelu. Wpływają one bezpośrednio na kapitał ludzki, czyli przygotowanie edukacyjne, wiedzę, trening i zdobyte umiejętności przedsiębiorcy, na cele działania i wreszcie na sposób osiągania tych celów, czyli strategie działania. Strategie działania są w modelu jedynym elementem, który bezpośrednio decyduje o odniesieniu sukcesu przedsiębiorczego. Osobowość wpływa na sukces poprzez wybór celów i strategii działania.

Ryc. 1. Model sukcesu w przedsiębiorczości

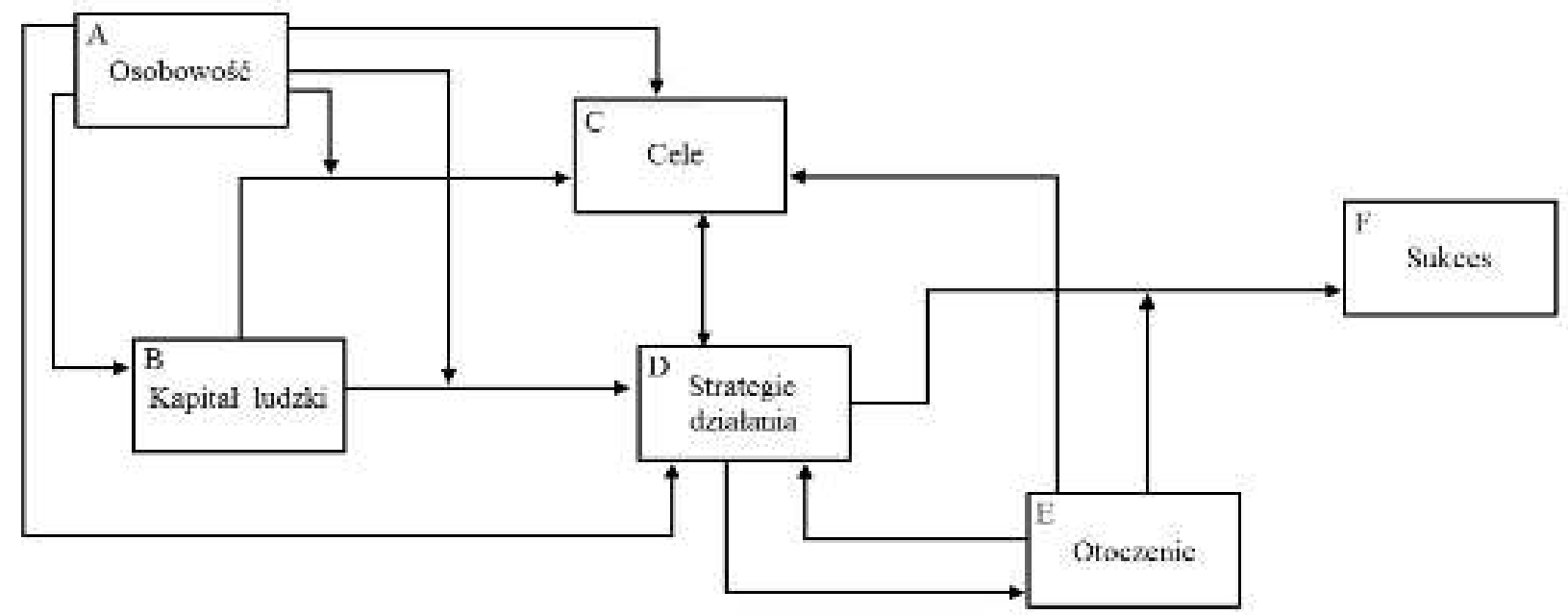

Opracowanie autorów na podstawie: Frese, de Kruif 2000.

Warto podkreślić ścisły związek między wyborem strategii działania bezpośrednio decydującej o sukcesie a zewnętrznym środowiskiem, w którym przedsiębiorca działa. Badania niemieckie (Rauch, Fresk 1998) wykazują na przykład, że planowe działanie (przygotowywanie biznesplanu) jest znacznie bardziej przydatne w bardzo niesprzyjającym przedsiębiorczości środowisku niż w przyjaznym.

\section{Wpływ płci i wieku na opinie i postawy przedsiębiorcze}

Badania postaw mieszkańców Gdyni w znacznej części skupiły się na poszukiwaniu odpowiednich cech w różnych grupach społeczno-demograficznych. Jednym z celów analizy było określenie zależności między płcią a postawami określanymi mianem proprzedsiębiorczych. Jedną z takich postaw jest wyrażanie opinii o wystarczającej wiedzy i umiejętnościach niezbędnych do otwarcia własnej działalności gospodarczej. Wyniki badań pozwalają stwierdzić, że wśród mieszkańców Gdyni swoją wiedzę oraz umiejętności w tym zakresie nieco wyżej cenią mężczyźni (56\% odpowiedzi twierdzących). W grupie kobiet odsetek ten wynosi 45\%. Jednocześnie, co w tym kontekście jest interesujące, pośród osób, którym się nie powiodło w prowadzeniu własnego przedsiębiorstwa, również przeważają mężczyźni. Co piąty z nich był zmuszony zakończyć działalność w ostatnich trzech latach, podczas gdy wśród badanych kobiet jedynie 14\% zrezygnowało z prowadzenia własnej firmy. Kiedy zapytano przedsiębiorców, czy zrezygnowaliby z własnej firmy, gdyby mieli możliwość zatrudnienia na etacie państwowym, przewaga kobiet była wyraźna; udział kobiet deklarujących rezygnację z własnej firmy w ogólnej liczbie badanych wyniósł 18\%, a udział mężczyzn - 12\%. W wywiadach z przed- 
siębiorcami pytano o kondycję finansową firmy mierzoną wielkością obrotów. W przypadku $60 \%$ firm prowadzonych przez mężczyzn zanotowano wzrost obrotów, a w podmiotach kierowanych przez kobiety wskaźnik ten wyniósł $45 \%$. Jednocześnie więcej kobiet niż mężczyzn (odpowiednio 9\% i 4\%) przyznało, że obroty ich firm maleją. W co trzecim przedsiębiorstwie zarządzanych przez kobiety obroty w ostatnich latach były bardzo zmienne; w firmach prowadzonych przez mężczyzn odsetek ten wyniósł zaledwie $17 \%$. Wyniki badań pozwalają stwierdzić, że mężczyźni chętniej podejmują ryzyko własnej działalności gospodarczej i nieco lepiej sobie radzą z jej prowadzeniem.

Badanie przeprowadzone na próbie 1000 osób miało na celu m.in. identyfikację cech, które według literatury przedmiotu winny charakteryzować osobę przedsiębiorczą i zaradną. Aby w miarę szczegółowo opisać cechy mieszkańców Gdyni, utworzono odpowiedni wskaźnik. Respondenci musieli ocenić swoją postawę, wybierając jedną odpowiedź z następujących par: „,jestem osobą bardzo aktywną w życiu” albo ,jestem osobą raczej mniej aktywną”; „szybko działającą” albo „odkładającą zadania na później”; „lubiącą działać samodzielnie” albo „raczej działającą w grupie”; „podejmującą chętnie ryzyko” albo „raczej niepodejmującą ryzyka”; „ciągle dużo uczącą się” albo „mniej przywiązującą uwagę do ciągłego uczenia się”; „mającą jasno określone cele w życiu” albo „osobą zmieniającą cele” oraz „osobą lubiącą zmiany w życiu” albo „ceniącą stabilizację”. Odpowiedziom określanym najczęściej przez badaczy jako przedsiębiorcze przypisano wartość „,", przeciwnym - wartość „,0”; następnie wszystkie punkty zsumowano. Im wyższa jest wartość wskaźnika, tym postawa jest bardziej przedsiębiorcza. Analiza wskaźnika określającego predyspozycje do samodzielnego prowadzenia firmy z zastosowaniem kryterium płci prowadzi do wniosku, że płeć nie wpływa na predyspozycje związane z postawą przedsiębiorczą (ryc. 2). Wynik badania wskazuje natomiast, że mimo braku większych różnic w postawach proprzedsiębiorczych między kobietami a mężczyznami, to mężczyźni są bardziej skłonni do podejmowania ryzyka i decyzji o otworzeniu własnej firmy. Kobiety równie często jak mężczyźni charakteryzują się postawami proprzedsiębiorczymi, jednak realizują te postawy w inny sposób: choć nie tak często jak mężczyźni są skłonne prowadzić własny biznes, to odpowiednie zachowania przejawiają się w czasie wykonywania pracy najemnej.

Ryc. 2. Wskaźnik postawy proprzedsiębiorczej według kryterium płci respondentów

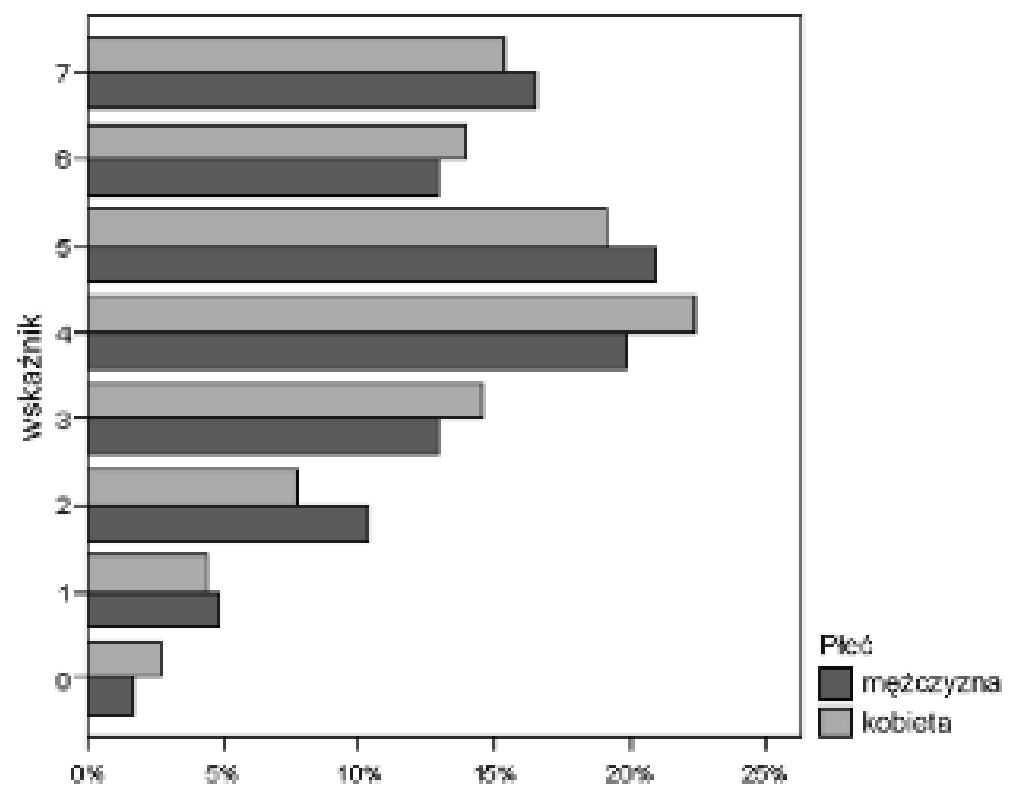

Opracowanie autorów na podstawie badań ankietowych. 
Wyniki badań postaw przedsiębiorczych zostały przeanalizowane z uwzględnieniem kryterium wieku. Jak się okazało, osoby starsze bardziej cenią pracę na etacie państwowym, która jest uważana za bardziej stabilną. Młodsi mieszkańcy Gdyni rzadziej są zdania, że praca w instytucji państwowej jest atrakcyjna. Zależność między wiekiem a planami dotyczącymi ewentualnego otwarcia firmy w przyszłości jest wyraźna (ryc. 3). W najmłodszych grupach wiekowych najwięcej osób przyznawało, że zamierza rozpocząć działalność gospodarczą, w tym szczególnie mieszkańcy, którzy dopiero weszli w wiek produkcyjny (27\%). Należy zauważyć, że co czwarty mieszkaniec z grupy wiekowej 30-39 lat oraz 40-49 lat również zamierza otworzyć firmę. Zapewne są to osoby, które po kilku bądź kilkunastu latach pracy najemnej nabrały doświadczenia zawodowego i zdobyły kapitał, który na obecnym etapie życia decydują się zainwestować we własną działalność gospodarczą.

Ryc. 3. Udział osób planujących otworzyć własną firmę według kryterium wieku

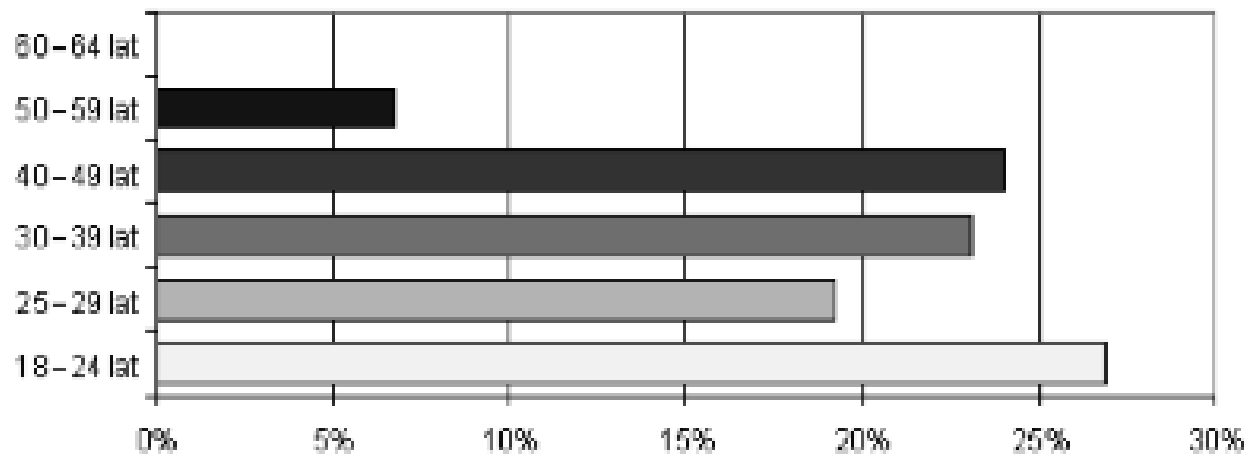

Opracowanie autorów na podstawie badań ankietowych.

Ryc. 4. Wskaźnik postawy proprzedsiębiorczej według kryterium wieku respondentów

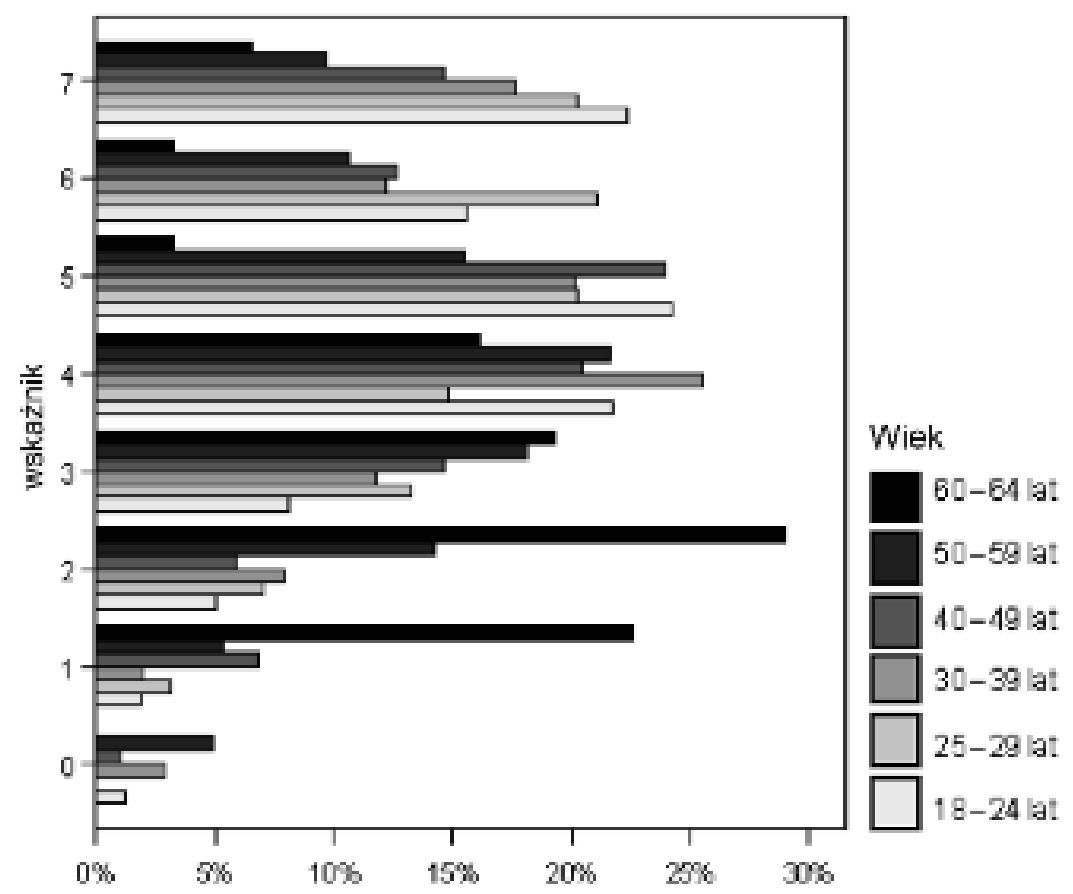

Opracowanie autorów na podstawie badań ankietowych.

Zależność między wiekiem a skłonnością do stwierdzenia, że respondent ma wiedzę i umiejętności, aby założyć firmę, jest także stosunkowo wyraźna. Więcej niż połowa respondentów z grup wiekowych 25-29 lat i 30-39 lat uważa, że mają te cechy. Są to osoby, których życie zawodowe, a po części także czas edukacji, przypadły na lata obowiązywania 
zasad wolnorynkowych w polskiej gospodarce. Stwierdzono również istotną korelację między wiekiem a postawą przedsiębiorczą określoną za pomocą przyjętego wskaźnika postawy przedsiębiorczej. Osoby młodsze w zdecydowanie większym stopniu wykazują zachowania przedsiębiorcze (wyższe wartości wskaźnika), co należy przyjąć z optymizmem w kontekście dalszego rozwoju przedsiębiorczości w mieście (ryc. 4).

\section{Postawy przedsiębiorcze a wykształcenie}

Badanie zachowań i postaw przedsiębiorczych prowadzono z uwzględnieniem wykształcenia respondentów. Wyniki wskazują, że wśród 12\% ogółu badanych deklarujących chęć prowadzenia własnego przedsiębiorstwa najwięcej jest osób z wykształceniem średnim i wyższym, mniej z zasadniczym zawodowym, a najmniej $-\mathrm{z}$ wykształceniem podstawowym. To podejście w pewnym stopniu znajduje odzwierciedlenie w opinii na temat atrakcyjności posady państwowej. Wymowny okazał się rozkład odpowiedzi w przypadku ocen skrajnych. Niemal co czwarty mieszkaniec z wykształceniem podstawowym uważa, że praca na etacie państwowym jest bardziej atrakcyjna, przy tylko $10 \%$ osób najsłabiej wykształconych zdecydowanie niezgadzających się z tym twierdzeniem.

Ryc. 5. Zależność wskaźnika postawy proprzedsiębiorczej od wykształcenia

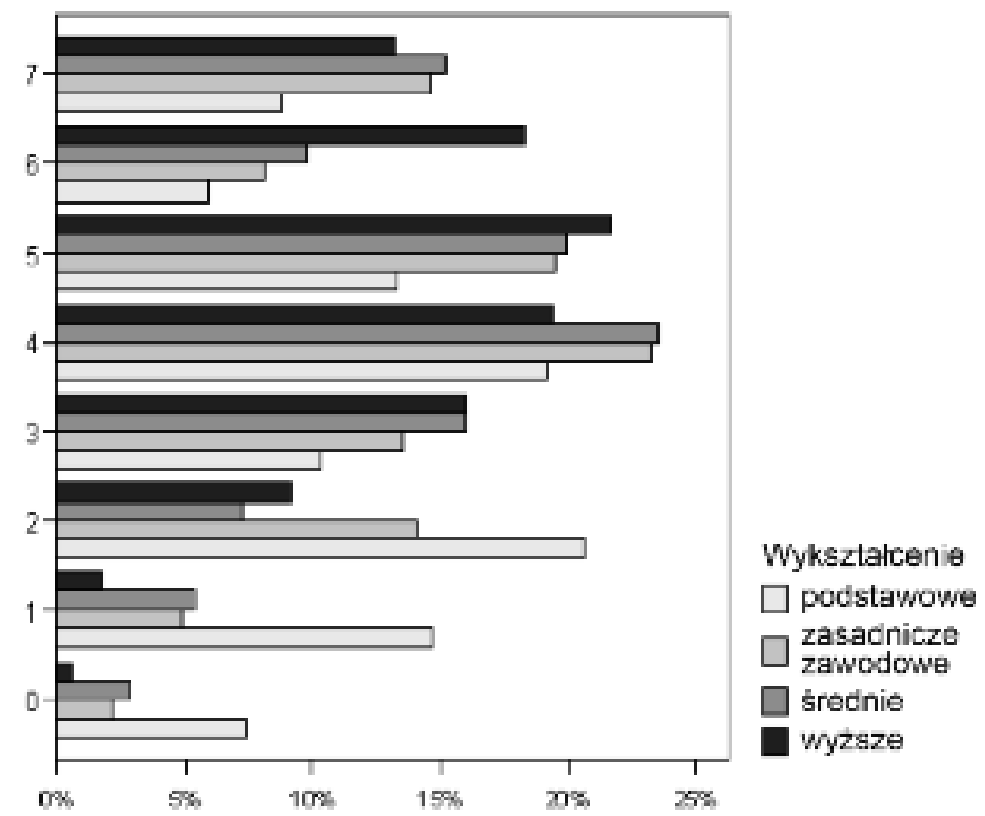

Opracowanie autorów na podstawie badań ankietowych.

Można postawić tezę, że bezpośredni kontakt z przedsiębiorcą sprzyja przyjmowaniu postawy przedsiębiorczej na zasadzie obserwacji, która - jeśli dotyczy dobrze prosperującej firmy - może stać się przykładem do naśladowania. Zatem taki kontakt może skutkować podjęciem decyzji o otwarciu działalności gospodarczej ,na własną rękę”, nierzadko w tej samej bądź pokrewnej branży. Znaczna większość gdynian nieprowadzących działalności (około 80\%) zna osobiście właściciela firmy. Znamienne jest przy tym, że im więcej lat edukacji mieli za sobą mieszkańcy Gdyni, tym częściej przyznawali, że znają właściciela firmy; wśród osób z wykształceniem wyższym odsetek wyniósł 90\%, a wśród osób z wykształceniem podstawowym - nieco ponad 70\%. Podobnie przedstawia się zależność pośród badanych nieposiadających firmy na temat wiedzy i umiejętności umożliwiających otwarcie własnej działalności gospodarczej. Co druga osoba uważa, że ma taką wiedzę i umiejętności, lecz kwestię tę wyraźnie różnicuje osiągnięty 
szczebel edukacji. Długość okresu kształcenia jest wprost proporcjonalna do przekonania o własnych umiejętnościach i mieści się w zakresie od 30\% dla osób z wykształceniem podstawowym do $60 \%$ dla badanych z wykształceniem wyższym.

Podejmując analizę znaczenia poziomu wykształcenia w kształtowaniu postaw przedsiębiorczych oraz rozwoju miejskiej przedsiębiorczości, skupiono również uwagę na potencjalnych zależnościach między cechami psychologicznymi uchodzącymi w literaturze przedmiotu za oznaki postaw przedsiębiorczych a poziomem wykształcenia respondentów. Omówiony wyżej wskaźnik syntetyczny ujawnił wyraźną zależność między poziomem wykształcenia a postawą proprzedsiębiorczną (ryc. 5). Szczególnie wyraźna jest różnica w owej postawie między osobami z wykształceniem podstawowym a pozostałą grupą badanych.

\section{Wpływ posiadania/nieposiadania firmy na opinie i postawy mieszkańców}

Jedną z analizowanych kwestii było poczucie społecznego szacunku wobec przedsiębiorców. Jest ono podobne u przedstawicieli obu analizowanych grup, ale zwraca uwage istotna przewaga odpowiedzi pozytywnych nad negatywnymi (50\% wobec $15 \%$; pozostali badani uznali, że właściciele firm są szanowani nie bardziej niż inni pracownicy). Społeczny odbiór osób przedsiębiorczych jest w Gdyni bardzo dobry, co podkreśla i umacnia znaną opinię o Gdyni jako mieście mającym i utrwalającym tradycję przedsiębiorczości. Pozytywne społeczne postrzeganie grupy przedsiębiorców wynika również z tego, że gdynianie są „oswojeni” z własnością prywatną i szanują ją, wiążą ją bowiem z rozwojem gospodarczym i społecznym miasta w całej jego historii.

Mieszkańców Gdyni i lokalnych przedsiębiorców poproszono o wskazanie tych umiejętności, które mogą skutecznie wspomóc prowadzenie firmy. Spośród sugerowanych odpowiedzi respondenci mieli wskazać maksymalnie dwie umiejętności, które ich zdaniem są najważniejsze. Za najważniejszy czynnik zarówno przedsiębiorcy, jak i pozostali respondenci uznali umiejętność organizacji pracy (odpowiednio 74\% i 58\%). Również umiejętność zarządzania zespołem uchodzi za istotny czynnik wspomagający rozwój firmy w zgodnej opinii osób posiadających firmę i nieposiadających firmy. Pozostałe cechy: znajomość języków obcych, znajomość obsługi komputera oraz znajomość podstaw księgowości nie są już tak istotne z punktu widzenia respondentów, a szczególnie przedsiębiorców (ryc. 6). Badani podkreślali ponadto w pytaniu otwartym raczej predyspozycje psychiczne i charakterologiczne, w tym pracowitość, wytrwałość, upór oraz wykształcenie.

Ryc. 6. Umiejętności uważane za najważniejsze w prowadzeniu firmy

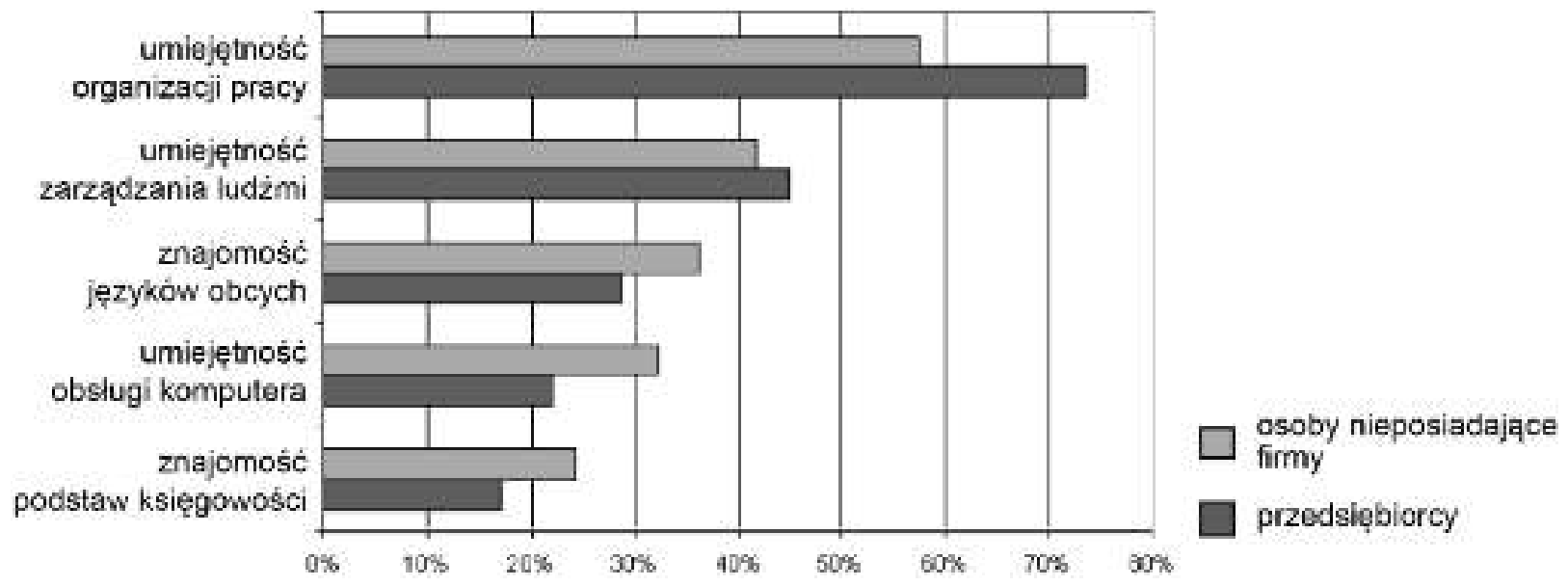

Opracowanie autorów na podstawie badań ankietowych. 
Nie mniej ciekawie przedstawiają się wyniki badań przedstawiające moment podjęcia decyzji o założeniu firmy. Przedsiębiorcy wskazywali, że należy ją podjąć zaraz po ukończeniu szkoły (45\% odpowiedzi wobec $32 \%$ wśród osób niebędących przedsiębiorcami). Równie często wskazywano, że własną działalność należy rozpocząć po kilku latach pracy w firmie prywatnej - udział przedsiębiorców wskazujących taką odpowiedź wyniósł prawie 40\%, podczas gdy wśród osób nieposiadających firmy nawet przekroczył 45\%. Najrzadziej uważano, że firmę należy otworzyć po kilku latach pracy „na państwowym” - przyznało tak zaledwie niecałe $20 \%$ przedsiębiorców i nieco ponad $20 \%$ osób nieposiadających firmy.

\section{Duch przedsiębiorczości}

Jednym z celów poznawczych niniejszego badania jest określenie, czy - oprócz aktywnych przedsiębiorców - w społeczności lokalnej Gdyni jest obecny „duch przedsiębiorczości” (spirit of entrepreneurship), znamionujący dalszy rozwój sektora MŚP. Pytano więc mieszkańców o ich aktywność w życiu oraz o te cechy, które - zdaniem badaczy - powinny charakteryzować osobę przedsiębiorczą i zaradną (ryc. 7). Poproszono wszystkich badanych o samookreślenie według tych cech: aktywności życiowej, otwarcia na zmiany w życiu, szybkości działania, współdziałania $\mathrm{z}$ innymi, podejmowania ryzyka, ustawicznego uczenia się i stawiania sobie celów w życiu.

Ryc. 7. Samoocena respondentów w kwestii cech kształtujących postawy przedsiębiorcze

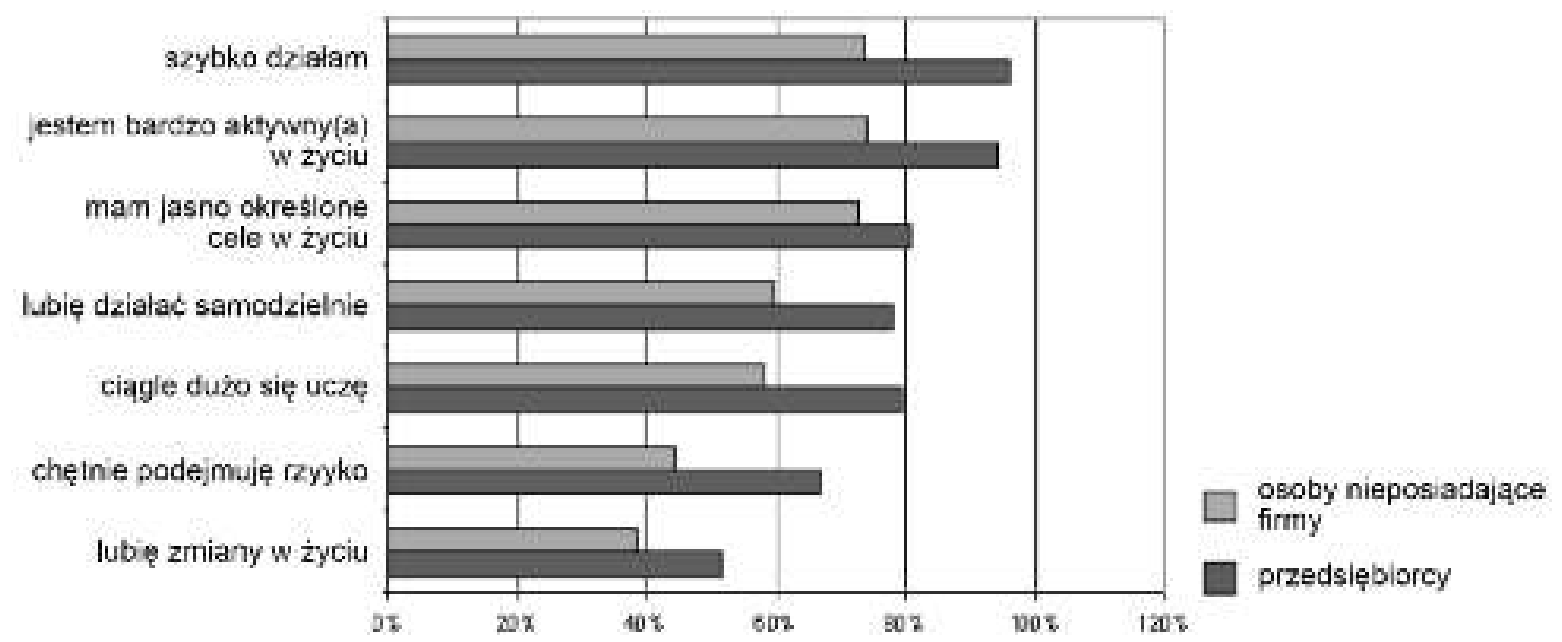

Opracowanie autorów na podstawie badań ankietowych.

W przypadku wszystkich wymienionych cech notuje się przewage pozytywnych odpowiedzi udzielonych przez działających przedsiębiorców nad odpowiedziami osób nieposiadających firmy. Należy jednocześnie zwrócić uwagę na istotny fakt: oprócz wspomnianej przewagi rozkład poszczególnych cech był identyczny, poczynając od najczęściej wymienianej szybkości działania, do najrzadziej wskazywanej - akceptacji częstych zmian w życiu. Znaczna większość przedsiębiorców (około 95\%) uznaje się za osoby szybko działające i aktywne, a 80\% ma wytyczone cele działania, ustawicznie się dokształca i lubi samodzielne działanie. Co drugi gdyński przedsiębiorca lubi zmiany w życiu. Można zatem sądzić, że portret lokalnego przedsiębiorcy kreślony przez samych właścicieli firm w znacznym stopniu odpowiada teoretycznemu ujęciu postawy przedsiębiorczej. Dla dokładniejszego zobrazowania różnic między obiema grupami skorzystano ze wskaźnika postaw przedsiębiorczych, który został omówiony wcześniej. Analiza wyników badań za jego pomocą pozwala zauważyć zasadnicze różnice postaw przedsiębiorczych między osobami prowadzącymi firmę a pozostałą grupą gdynian (ryc. 8). Oprócz dużej przewagi tego wskaźnika wśród przedsiębiorców należy zwrócić uwagę na to, że postawy większości mieszkańców Gdyni 
odpowiadają tym cechom, które określa się mianem proprzedsiębiorczych; gdynianie mają zatem duży potencjał służący miejskiej przedsiębiorczości.

Ryc. 8. Wskaźnik postawy proprzedsiębiorczej

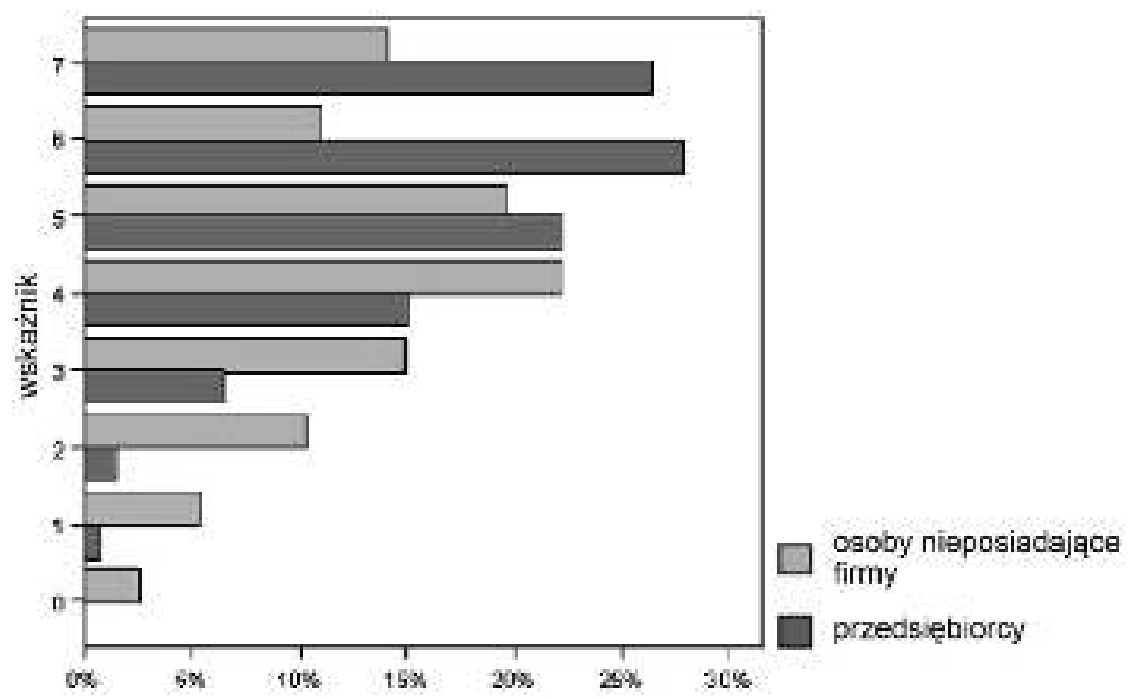

Opracowanie autorów na podstawie badań ankietowych.

W celu przeanalizowania występowania postaw przedsiębiorczych, a co za tym idzie - ducha przedsiębiorczości wśród właścicieli firm, postanowiono utworzyć portret psychologiczny typowego przedsiębiorcy. Posłużono się pogłębionymi wywiadami z zastosowaniem metody kuli śnieżnej, co pozwoliło uzyskać wyczerpujące informacje od stu przedsiębiorców - właścicieli małych i średnich firm z Gdyni. Na podstawie serii pytań opisujących pośrednio cechy charakterologiczne badanych respondentów oraz ich reakcje na różne sytuacje w życiu prywatnym i zawodowym ustalono, jaki udział badanych właścicieli firm odpowiada teoretycznemu modelowi wizerunku przedsiębiorcy, charakteryzowanemu konkretnymi cechami mentalnymi i zachowaniami. Wśród cech opisujących ducha przedsiębiorczości są kreatywność i pewność siebie. Na podstawie wielu pytań pośrednich można stwierdzić, że więcej niż połowa przedsiębiorców cechuje się wysokim stopniem kreatywności i pewności siebie (ryc. 9). Zwraca jednak uwagę to, że aby zostać przedsiębiorcą stopień ten nie musi być wysoki; prawie 40\% badanych cechowała się średnim stopniem kreatywności.

Ryc. 9. Stopień kreatywności i pewności siebie wśród ankietowanych przedsiębiorców

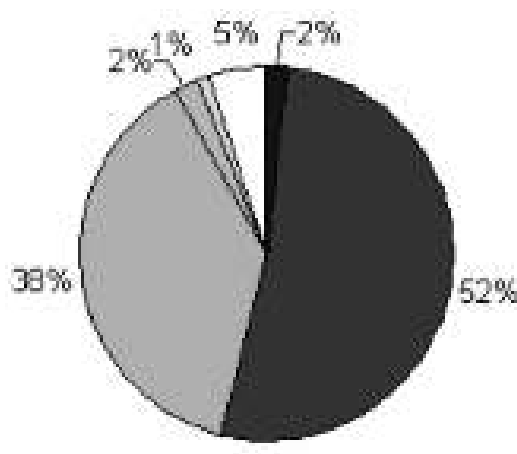
- bardzo kreatywny i pewny siebie
- kreatywny i pewny siebie
口 srednio kreatywny i pewny siebie
a malo kreatywny i pewny siebie
口 brak kreatywnosci i pewnosei siebie
a brak danych

Opracowanie autorów na podstawie badań ankietowych.

Właściciele gdyńskich firm dużą wagę przykładają do samodzielnego inicjowania przedsięwzięć i do planowania. Można przypuszczać, że te cechy są ważniejsze dla powodzenia działalności gospodarczej niż kreatywność i pewność siebie, aż 70\% badanych okazało się bowiem dobrymi lub bardzo dobrymi planistami (ryc. 10). 
Ryc. 10. Poziom inicjatywy i planowania pośród badanych przedsiębiorców

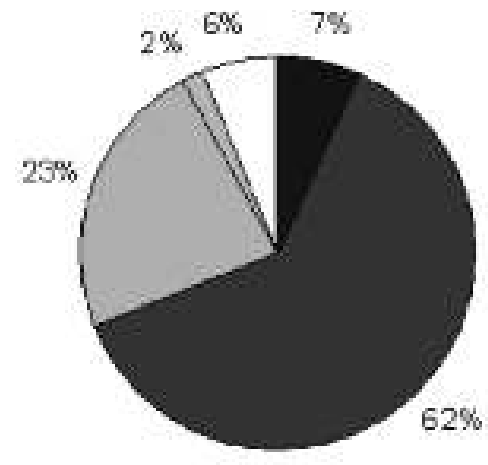

$$
\begin{aligned}
& \text { - świetny planista i inicjator } \\
& \text { - dobry planista i inicjator } \\
& \text { a przeciętny planista i inicjator } \\
& \text { akiepski planista i inicjator } \\
& \square \text { brak danych }
\end{aligned}
$$

Opracowanie autorów na podstawie badań ankietowych.

Nieco mniej respondentów było zdeterminowanych w samodzielnym dążeniu do celu. Mocno zdeterminowanych lub wystarczająco zdeterminowanych było niecałe $60 \%$ badanych (ryc. 11 ). Należy zwrócić uwagę, że wśród przedsiębiorców nie było osób słabo lub bardzo słabo zdeterminowanych. Zasadniczo wszyscy właściciele firm w mniejszym lub większym stopniu wykazywali wolę zmagania się z przeciwnościami losu, co jest kluczową cechą przedsiębiorcy.

Ryc. 11. Poziom determinacji we własnych działaniach pośród badanych przedsiębiorców
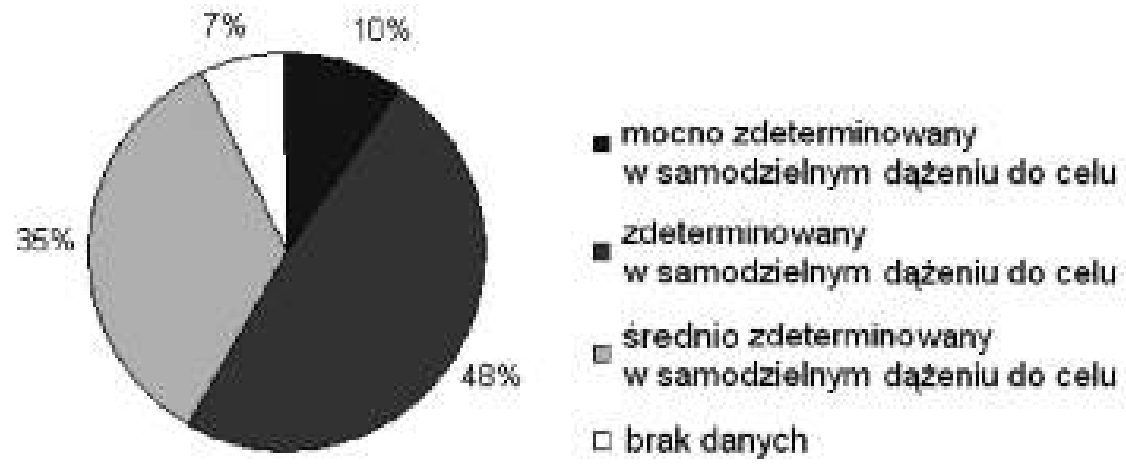

Opracowanie autorów na podstawie badań ankietowych.

Bardziej znaczącą cechą opisującą gdyńskich przedsiębiorców jest poziom zaradności. Okazało się, że ponad 20\% osób jest bardzo zaradnych, a kolejne 70\% - zaradnych (ryc. 12). Wynik badania wskazuje, że aby utrzymać firmę na rynku jej właściciel musi umieć radzić sobie w trudnych i nieoczekiwanych sytuacjach.

Ryc. 12. Poziom zaradności w grupie badanych przedsiębiorców

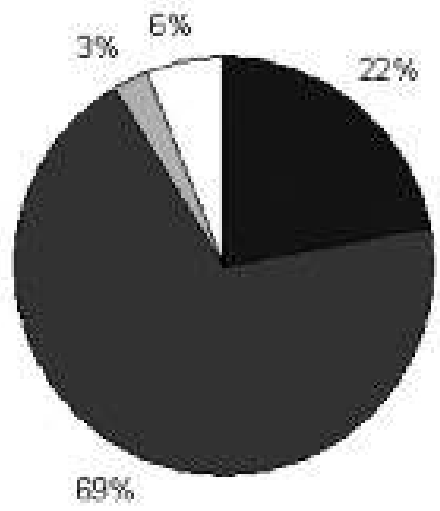

$$
\begin{aligned}
& \text { - bardzo zaradny } \\
& \text { - zaradny } \\
& \text { - srednio zaradny } \\
& \text { - brak danych }
\end{aligned}
$$

Opracowanie autorów na podstawie badań ankietowych. 
Pogłębione badania na grupie 100 przedsiębiorców pozwoliły określić poziom umiejętności zarządzania ludźmi i organizowania pracy. Pośrednie pytania skierowane do właścicieli małych i średnich firm umożliwiły określenie kilku typów przedsiębiorców według poziomu ich umiejętności menedżerskich. Wyniki wskazały, że 25\% badanych można określić mianem idealnych lub bardzo dobrych menedżerów, a kolejne 36\% - dobrych kierowników (ryc. 13). Mniejsza część badanych cechowała się przeciętnymi lub niewystarczającymi umiejętnościami zarządzania ludźmi, jednak wydaje się, że grupa ta jest zbyt liczna.

Ryc. 13. Poziom umiejętności menedżerskich wśród ankietowanych przedsiębiorców

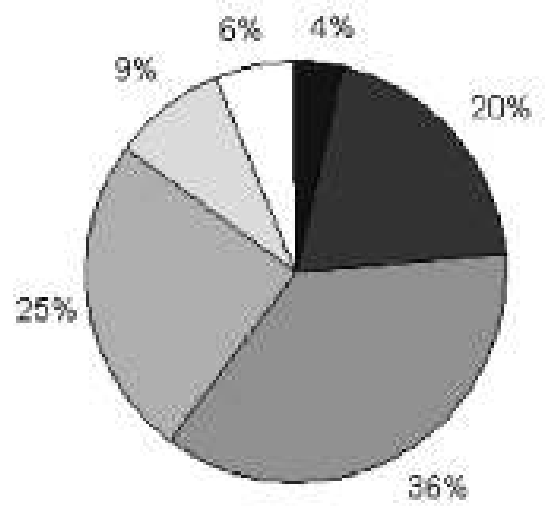

- idealny menedżer
a bardzo dobry menedżer
$\square$ dobry menedżer
$\square$ średni menedżer
$\square$ kiepski menedżer
$\square$ brak danych

Opracowanie autorów na podstawie badań ankietowych.

\section{Czynniki wpływające na ksztaltowanie się postaw przedsiębiorczych}

Wyniki badań stały się podstawą nakreślenia obrazu lokalnego przedsiębiorcy i umożliwiły identyfikację cech właściwych postawom przedsiębiorczym nie tylko wśród przedsiębiorców, ale także wśród pozostałych mieszkańców Gdyni. W przypadku właścicieli firm zebrane wyniki badań posłużyły do nakreślenia wizerunku typowego przedsiębiorcy, a analiza opinii, zachowań i predyspozycji pozostałych badanych dały odpowiedź na zasadnicze pytanie: czy w społeczności lokalnej Gdyni drzemie potencjał, który może być wykorzystany na rzecz rozwoju miejskiej przedsiębiorczości.

Czynniki, które wpływają na kształtowanie postaw proprzedsiębiorczych, a w konsekwencji na rozwój przedsiębiorczości, można scharakteryzować, opierając się na kategoriach wyróżnionych w modelu działań przedsiębiorczych (ryc. 1). Składowe elementy tego modelu, które ostatecznie decydują o powodzeniu działań przedsiębiorczych, to cechy osobowości jednostki, kapitał, jaki sobą reprezentuje na rynku pracy, cele oraz sposoby działań, które prowadzi w określonych warunkach środowiska lokalnego. Spośród wymienionych elementów wpływających na sukces działań przedsiębiorcy, kapitał ludzki oraz cechy otoczenia są potencjalnym sferami możliwych działań na rzecz stymulowania postaw przedsiębiorczych.

Kapitał ludzki stanowi akumulację wiedzy i umiejętności, z którymi przedsiębiorca podejmuje realizację przyjętych celów. Do tradycyjnych miar kapitału ludzkiego należą: liczba lat edukacji, doświadczenie zawodowe oraz organizacyjne i kierownicze (Bruederl i in. 1992, 1998, Preisendoerfer, Voss 1990). Decydujące znaczenie w kształtowaniu kapitału ludzkiego ma system edukacji funkcjonujący w środowisku lokalnym. Prowadzone w Polsce badania nad zależnością postaw przedsiębiorczych od wykształcenia wykazują niewielki jego wpływ na stymulację tych postaw (Jerschina 1998, 2000). Wykształcenie, które uczniowie otrzymują w szkołach wszystkich rodzajów, w niewielkim stopniu budzi chęć bycia przedsiębiorcą i prowadzenia własnej działalności przedsiębiorczej; o tym, czy chcieliby prowadzić działalność na własny rachunek, badani decydują niezależnie od posiadanej wiedzy. 
Badania w Gdyni pozwoliły stwierdzić, że liczba lat edukacji wpływa na postawy przedsiębiorcze. Postawy te nie muszą się jednak bezpośrednio przekładać na chęć rozpoczęcia własnej działalności gospodarczej.

Jak wynika z badań, obecnie pośród przedsiębiorców przeważają absolwenci liceów profilowanych, szkół policealnych, studiów inżynierskich, magisterskich na uczelniach technicznych oraz zasadniczych szkół zawodowych. Można więc stwierdzić, że w Gdyni na otwarcie firmy częściej decydują się osoby z wykształceniem o określonym profilu zawodowym. Można by sądzić, że są one bardziej zdecydowane i lepiej przygotowane do podjęcia konkretnej działalności gospodarczej. Co znamienne, właściciele lokalnych firm - jako doświadczeni przedsiębiorcy - częściej niż pozostali respondenci wskazują na zasadniczą szkołę zawodową oraz technikum jako najlepsze szkoły, które przygotowują do prowadzenia własnej firmy. Potwierdzeniem takiego podejścia jest przeważający wśród przedsiębiorców pogląd, że pracę na własny rachunek należy rozpocząć od razu po szkole, co sankcjonuje opinie przedsiębiorców o szkołach zawodowych zasadniczego i średniego szczebla jako odpowiednim pułapie edukacyjnym umożliwiającym samodzielne prowadzenie firmy. Interesujący w tym kontekście jest fakt, że jednocześnie tylko trzecia część osób prowadzących działalność gospodarczą zetknęła się w szkole z informacjami o prowadzeniu firmy. Honorując fakt, że działalność gospodarczą podejmują częściej absolwenci szkół o określonych profilach kształcenia, należy zwrócić większą uwagę na rozszerzenie oferty edukacyjnej szczególnie o te elementy, które skutecznie kształtują umiejętności kierowania zespołem oraz organizacji pracy i są wymieniane przez samych przedsiębiorców jako najważniejsze z punktu widzenia prowadzenia własnej działalności.

Mniejszy udział osób lepiej wykształconych na poziomie ogólnym (akademickim), niepodejmujących działalności gospodarczej mimo lepszej deklarowanej edukacji proprzedsiębiorczej, może wynikać z dwojakiego rodzaju przyczyn. Po pierwsze, może on oznaczać, że szersze wykształcenie i wynikająca z niego wiedza na temat realnych zagrożeń i ryzyka związanego z własną działalnością gospodarczą powodują większą ostrożność i brak chęci do podjęcia decyzji o prowadzeniu własnej firmy. Paradoksalnie zatem wyższe wykształcenie może tworzyć większe bariery natury psychologicznej. Po wtóre, wysokie kwalifikacje otwierają większe możliwości znalezienia atrakcyjnej posady w sektorze budżetowym lub prywatnym w dużym przedsiębiorstwie na stanowisku specjalisty.

Wydaje się, że opinie formułowane przez osoby nieposiadające własnej firmy - spośród których co ósma deklaruje chęć zostania przedsiębiorcą - mogą wskazywać na prawdopodobny kierunek zmian w strukturze wykształcenia pośród właścicieli podmiotów gospodarczych na rzecz osób lepiej wykształconych i absolwentów kierunków ogólnych (akademickich). Zarazem można oczekiwać, że zmieni się sposób prowadzenia firmy - ze spontanicznego i nieplanowanego, dyktowanego doraźnymi potrzebami młodego nadal wolnego rynku, na planowany, stabilny i podparty biznesplanem. Oczywiście, na rynku znajdzie się miejsce zarówno dla firm prowadzonych przez fachowców w konkretnej branży, najczęściej bazujących jedynie na pracy własnej (co obserwuje się obecnie), jak i dla nowej fali przedsiębiorców, mających solidne teoretyczne przygotowanie do samodzielnego zarządzania firmą, choć niekoniecznie wykształconych w wąskim profilu zawodowym. Dla rynku pracy wzrost liczby firm kierowanych przez przedsiębiorców-menedżerów jest niezwykle cenny, zakłada bowiem wzrost liczby firm zatrudniających co najmniej jednego pracownika, a więc firm w pełni zorientowanych na rynkową działalność przedsiębiorczą. Wzrost liczby tego typu przedsiębiorców na rynku lokalnym byłby weryfikacją działań na rzecz pobudzania przedsiębiorczości w lokalnym systemie kształcenia. 
Nie ulega wątpliwości, że stosunkowo niewiele osób mających trudności ze zdobyciem pracy ma cechy osobowości wspomagające podjęcie tak trudnej życiowo inicjatywy. Dlatego też ważne jest, by osoby pozostające bez pracy miały jak największy dostęp nie tylko do szkoleń zawodowych pod kątem wymogów rynku pracy i istniejącego na nim zapotrzebowania, ale nade wszystko - do treningów psychologicznych oraz szkoleń pobudzających własną aktywność i samodzielność. Odpowiednio formułowany system zachęt z czytelnym podkreśleniem zalet i profitów wynikających z posiadania własnej firmy powinien być równie często stosowany jak inne działania na rzecz zapobiegania bezrobociu.

Pomimo wyraźnych działań władz miasta na rzecz poprawy jakości obsługi, nadal 40\% właścicieli firm uważa, że nie odczuwa tego wsparcia ${ }^{1}$. Jest to dość poważny sygnał dla lokalnego samorządu, poprawa współpracy pomiędzy sektorem MŚP a władzami miejskimi mogłaby bowiem umocnić pozytywny efekt dynamicznego rozwoju miejskiej przedsiębiorczości i generowanych przez nią przychodów. Skoro $80 \%$ przedsiębiorców uznaje, że prosperuje bardzo dobrze i ma poczucie sukcesu, to możliwość skorzystania np. z europejskich środków pomocy, o które tak skutecznie zabiegają władze Gdyni, wywoła dodatkowy pozytywny impuls rozwojowy $\mathrm{w}$ sektorze MŚP, a to $\mathrm{z}$ kolei przełoży się bezpośrednio na poprawę sytuacji na lokalnym rynku pracy. Na tym polu tkwią jeszcze duże rezerwy, $40 \%$ przedsiębiorców odnosi się bowiem sceptycznie do finansowania działalności ze źródeł UE, a co trzeci badany w ogóle nie brał pod uwagę starań o fundusze europejskie.

Wśród powodów, dla których te osoby nie podjęły dotychczas działalności na własny rachunek, brak odpowiednich predyspozycji czy też wiedzy nie należały do najbardziej istotnych. Najczęściej wymieniano brak odpowiednich środków finansowych na podjęcie działalności gospodarczej oraz zbyt skomplikowane przepisy prawne. To potwierdza po raz kolejny tezę, że w społeczności lokalnej Gdyni tkwi potencjał, który - odpowiednio pobudzony - może spowodować wzrost liczby przedsiębiorców.

\section{Możliwe kierunki działań samorządu lokalnego na rzecz podniesienia aktywności i ksztaltowania postaw przedsiębiorczych}

Do działań długofalowych o kluczowym znaczeniu należą inicjatywy w dziedzinie edukacji młodzieży. Największa liczba przedsiębiorców ukończyła licea profilowane bądź technika i szkoły policealne. Te szkoły zatem powinny być przede wszystkim przygotowane do kształcenia i stymulowania postaw przedsiębiorczych. Z wypowiedzi respondentów wynika, że wpływ szkoły na przygotowanie do podjęcia samodzielnej działalności przedsiębiorczej jest znikomy. Szkoły zawodowe przygotowują do wykonywania zawodu, dają określone kwalifikacje zawodowe, jednak zupełnie nie przygotowują do podejmowania własnej działalności gospodarczej. Konieczne wydaje się upowszechnienie we wszystkich typach szkół średnich zawodowych zajęć z przedsiębiorczości, które powinny stymulować postawy kreatywne i innowacyjne, a przede wszystkim dostarczać podstawowej wiedzy: jak prowadzić własną działalność, jak ją planować i jak nią zarządzać, jakie są dostępne formy wsparcia finansowego itp. Szkoły powinny w szerszym zakresie niż tylko w formie praktyk zawodowych współpracować z przedsiębiorcami, którzy odnoszą sukcesy w zawodach będących przedmiotem nauczania w szkołach, aby na ich bezpośrednim przykładzie uczyć młodzież i inspirować ją do podejmowania wyzwań. W szkołach tych powinno się także kształtować etos nauczanego zawodu. Przekonanie o wartości wykonywanej profesji i jej wysoka ocena tworzą kapitał wartości społecznej

\footnotetext{
${ }^{1}$ Niniejszy artykuł jest streszczeniem wyników badań przeprowadzonych na zlecenie samorządu Gdyni, pominięto zatem niektóre aspekty badań zamieszczonych w raporcie pt. Mieszkańcy Gdyni wobec przedsiębiorczości, a zaprezentowano ważniejsze wnioski.
} 
zawodu, na którym budowane są sukcesy poszczególnych przedsiębiorców. Dowodem na to, że zetknięcie się nawet z podstawową informacją na temat prowadzenia własnej działalności gospodarczej na etapie edukacji ma wpływ na kształtowanie postaw przedsiębiorczych, jest wynik badania ankietowego. Wykazało ono, że wśród przedsiębiorców jest o około 10\% więcej respondentów, którzy w trakcie edukacji zetknęli się z zagadnieniami przedsiębiorczości niż wśród respondentów niebędących przedsiębiorcami.

Kapitał inwestycyjny w przytłaczającej większości niemal $80 \%$ badanych firm pochodził z własnych zasobów finansowych. Jednocześnie znikomy procent przedsiębiorców skorzystał z finansowych programów pomocowych oferowanych przez różne instytucje. Odpowiedź na pytanie, skąd wziąć pieniądze na uruchomienie działalności firmy, a zatem wskazywanie możliwych źródeł kredytowania i wsparcia finansowego przedsiębiorczości, to bez wątpienia zadanie, a jednocześnie pole do aktywnej działalności władz miasta. Mimo że oferowane są szkolenia na temat pozyskiwania dotacji unijnych, to jednocześnie gdyński sektor MŚP w niewielkim stopniu jest zainteresowany pomocą unijną. Zmiana powszechnej wśród przedsiębiorców opinii, że dotacje unijne są przeznaczone tylko dla dużych firm, przezwyciężenie niewiary w możliwość ich pozyskania, przełamanie przekonania o zbyt skomplikowanych i przez to niedostępnych procedurach pozyskiwania - mogą w poważnym stopniu zwiększyć potencjał przedsiębiorczości w mieście. Kształtowanie postawy nakierowanej na poszukiwanie środków finansowych na uruchomienie działalności własnej firmy z licznych dostępnych źródeł wsparcia finansowego, a nie opieranie się jedynie na zasobach własnych i rodziny, jest zadaniem edukacji proprzedsiębiorczej na wszystkich jej szczeblach i we wszystkich formach. Przełamanie mentalnego ograniczenia, jakim jest przekonanie o konieczności posiadania własnego kapitału wyjściowego do podjęcia działalności przedsiębiorczej, może przynieść pożądane efekty.

Należy także zweryfikować charakter szkoleń i treningów. Warto zwrócić uwagę, że znajomość podstaw księgowości znalazła się na ostatnim miejscu wśród umiejętności uważanych za ważne w prowadzeniu firmy. Portret psychologiczny przedsiębiorcy wyraźnie wykazał, że duża część z nich ma niewystarczające umiejętności menedżerskie. Wsparcie szkoleniowe w tym zakresie jest zatem pomocne i oczekiwane, szczególnie że większość przedsiębiorców wskazuje na umiejętności organizacji pracy oraz zarządzania ludźmi jako kluczowe w prowadzeniu firmy z sukcesem.

Działania na rzecz rozwoju gdyńskiego sektora MŚP powinny prowadzić do zmian ilościowych, a więc wzrostu liczby działających podmiotów, ale także do zmian jakościowych parametrów charakteryzujących ten sektor. Poprawa cech jakościowych przedsiębiorczości powinna wiązać się ze wzrostem udziału przedsiębiorców z wyższym wykształceniem, posiadających umiejętności zarządzania firmą. Prowadzenie planowanej działalności gospodarczej opartej na biznesplanie, znajomość języków obcych, umiejętność wykorzystania w działalności gospodarczej techniki komputerowej - to pakiet podstawowych umiejętności dających podstawy do funkcjonowania z sukcesem w otwartej, konkurencyjnej gospodarce rynkowej.

W celu pozyskiwania dobrze wykształconych, otwartych, kreatywnych młodych ludzi do działalności w sektorze przedsiębiorczości konieczne jest też utrwalanie pozytywnego wizerunku przedsiębiorcy, systematyczne budowanie etosu zawodów pozwalających rozwinąć działalność przedsiębiorczą. Pożądane rezultaty może przynieść współdziałanie samorządu, szkół i prasy lokalnej. Działania te powinny zmierzać ku temu, aby przedsiębiorczość nie była wyborem z konieczności, z braku możliwości znalezienia innych form zatrudnienia, a tym samym nie była narażona na negatywną selekcję potencjalnie nią zainteresowanych. Powinna być sferą działalności wybieraną na równi z innymi. Tym samym charakterystyki przedsiębiorców nie powinny różnić się na niekorzyść od przeciętnych parametrów lokalnego kapitału ludzkiego. 
Przedsiębiorczość oparta na takim kapitale będzie trwałym elementem rozwoju społeczeństwa Gdyni opartego na wiedzy.

\section{Literatura}

1. Babbie E., 2004, Badania spoleczne w praktyce, PWN, Warszawa.

2. Bruerdel J., Preisendoerfer P., 1998, Network support and the success of newly founded businesses, "Small Business Economics", No. 10.

3. Bruerdel J., Preisendoerfer P., Ziegler R., 1992, Survival chances of newly founded business organization, “American Sociological Review”, No. 57, Menasha.

4. Frese M., de Kruif M., 2000, Psychological success factors of entrepreneurship in Africa: a selective literature review [w:] M. Frese (red.), Success and failure of micro business owners in Africa: psychological approach, Quorum Books, Westport CT.

5. Gibb A.A., 1993, Enterprise culture and education: Understanding enterprise education and its links with small business, entrepreneurship and wider educational goals, "International Small Business Journal", Vol. 11, No.3.

6. Jerschina J., 1998, Orientacje na przedsiębiorczość w Polsce na tle krajów Europy Środkowej $i$ Wschodniej. Elity $i$ społeczeństw, „Przegląd Socjologiczny”, t. XLVII, Łódź.

7. Jerschina J., 2000, Postawy przedsiębiorczości w Polsce na tle krajów Europy Środkowej i Wschodniej. Elity i społeczeństwa (kontynuacja), „Przegląd Socjologiczny”, t. XLIX, Łódź.

8. Pomykało W., 1995. Encyklopedia biznesu, Fundacja Innowacja, t. 1, Warszawa.

9. Preisendoerfer P., Voss T., 1990, Organizational morality of small firms: the effects of entrepreneurial age and human capital, "Organization Studies", No. 11.

10. Sztucki T., 1996. Marketing przedsiębiorcy i menadżera, Rynek - marketing - nabywca, Agencja Wydawnicza „Placet”, Warszawa.

\section{Entrepreneurial Attitudes among Gdynia Citizens}

Generally the research on the entrepreneurship concerns its economic dimension. There are many projects and analyses of economic conditions in small and medium enterprises (SME) where factors and barriers of competitiveness have been described. The aim of this paper is mainly social and psychological aspects of entrepreneurship. According to the authors these aspects are essential for the decisions to start up the business and make it possible to prosper and to be continued with satisfaction out of it. This paper is an attempt to identify features of proper entrepreneurial attitudes among not only business owners in Gdynia, but also among Gdynia citizens who are not owners. The basis for the analysis of opinions, enterprising behaviour and predisposition to run a business, was questionnaire survey conducted in 2007. The results answered the key question: Has the local society a potential that can be used to develop urban entrepreneurship? 